www.jmscr.igmpublication.org

Index Copernicus Value: 79.54

ISSN (e)-2347-176x ISSN (p) 2455-0450

crossrefDOI: https://dx.doi.org/10.18535/jmscr/v7i3.131

Journal Of Medical Science And Clinical Research

\title{
Application of Storytelling Methods in Optimizing Fruit and Vegetable Consumption in Preschool Children
}

\author{
Authors \\ Tri Wiji Lestari ${ }^{1 *}$, Warijan ${ }^{2}$, Sugih Wijayati ${ }^{3}$ \\ ${ }^{1,2,3}$ Nursing Department, Ministry of Health Polytechnic, Semarang, Indonesia \\ *Corresponding Author \\ Tri Wiji Lestari \\ Email: trilestari_68@yahoo.com
}

\begin{abstract}
Background: Adequate nutrition is one of the critical factors in the development process of pre-school age children. Regular consumption of fruit and vegetables can optimize nutrient intake so that growth and development run optimally. Unfortunately, consumption of fruits and vegetables in pre-school children is still low. This is due to a lack of knowledge about the types, benefits, and importance of fruits and vegetables.
\end{abstract}

Objective: This study aims to prove the application of the storytelling method in optimizing the knowledge and consumption of fruits and vegetables in pre-school children in the city of Semarang.

Methods: The design of this study used Experimental Quasy with pretest-posttest control group design. This research was conducted from September to November 2017 with a total sample of 120 respondents.

Conclusion: The results showed that the application of storytelling affected increasing the knowledge and practice of eating fruits and vegetables at the age of pre-school children in Semarang ( $p$ value 0.05 ). Based on this, the application of storytelling can be used as an alternative method in conducting health education so that pre-school age children can consume fruits and vegetables.

Keywords: Children's booklet, storytelling, fruit, and vegetable consumption.

\section{Background}

The pre-school age period is a period of rapid growth. These developments include emotional, cognitive and psychosocial development. For the growth process to run optimally, nutrition is needed adequate (Kania,2006). Some critical elements required by the child for the growth process include iodine, calcium, phosphorus, magnesium, iron, fluorine, vitamins $\mathrm{A}, \mathrm{B} 12, \mathrm{C}$ and D. These elements are found in many fruits and vegetables (Suyitno, 2008).

At the age of pre-school children, consumption of fruits and vegetables is still low. This is often the main problem that causes not optimal growth and development (Persada, 2011). Based on research conducted by Rohimah (2015), mentioned that the 
amount of vegetable consumption in pre-school children is still below the minimum recommended standard of balanced nutrition guidelines in 2013. This lack of vegetable consumption is because children never get a variety of different vegetables, parents pay less attention to the types of processed vegetables that are varied so that when children get a vegetable menu, new children tend to refuse.

According to the Indonesian Ministry of Health, the proportion of consumption of vegetables and fruits recommended by WHO for healthy living is 400 grams/day which consists of 250 grams of vegetables and 150 grams of fruit. According to the national vegetable consumption survey from 2007 to 2013, it was found that the average vegetable consumption of $46 \mathrm{kcal} /$ day was 38 kcal/day (Bestari GS, 2014).

In Indonesia, the recommended consumption of vegetables and fruits is 300-400 grams per person/day for toddlers and school-age children (RI Ministry of Health, 2013). An estimated 80\% of children in this world do not like vegetables, even though vegetables are a significant contributor to vitamin nutrition, minerals, and fiber for a balanced diet in children and adults (Lubis, 2012).

The impact of low consumption of vegetables and fruits in pre-school children is that nutrition is not optimal. Nutritional deficiencies due to low consumption of vegetables will affect growth that is not optimal (Hikmah, 2016). For this reason, efforts are needed so that pre-school age children can consume vegetables and fruits according to standards.

Children are also easily attracted to a story. Not only that, children tend to follow the characters they want. This condition can be used as a way to change the mindset of pre-school age children to the consumption of vegetables and fruit. The form of stimulation that can be given is storytelling by using interesting media namely picture books and dolls.

The provision of visual and verbal stimulation in children is stimulation that is readily accepted by children in absorbing information (Hikmah,
2016). By using illustrated storybook media and children's dolls, it will be easier to receive messages that will be accepted. Based on this, it is expected that pre-school age children have a new outlook on the consumption of vegetables and fruit. The statistical test used is the T-Test and Mann Whitney Test.

\section{Methods}

This study used Quasy Experiment with a pretestposttest nonequivalent control group design. This research was conducted in September-November 2018 in the kindergarten of Semarang City. The total sample of 120 respondents consisted of 2 groups, namely the intervention group as many as 60 respondents given storytelling using booklet media, and the control group as many as 60 respondents were given traditional health education. The material provided regarding the knowledge and practice of consuming vegetables and fruits. The independent variable in this study is storytelling, while the dependent variable is the consumption of fruit and vegetables.

\section{Results and Discussion}

Based on the results of the study, it was shown that before being given treatment most of the respondents had knowledge of the types of fruit, but did not yet have awareness about the benefits of fruit. This happened because the respondents had never received knowledge about the benefits of fruit. Learning activities in schools only teach about the kinds of fruit. After being given treatment in each group, respondents' knowledge of the types and benefits of fruit has increased. The increase occurs mainly in the treatment groups. 
Table 1 Overview of knowledge about types and benefits of fruit before and after treatment

\begin{tabular}{|c|c|c|c|c|c|c|c|c|}
\hline \multirow{3}{*}{$\begin{array}{l}\text { Education } \\
\text { Level }\end{array}$} & \multicolumn{4}{|c|}{ Treatment } & \multicolumn{4}{|c|}{ Control } \\
\hline & \multicolumn{2}{|c|}{ Pre } & \multicolumn{2}{|c|}{ Post } & \multicolumn{2}{|c|}{ Pre } & \multicolumn{2}{|c|}{ Post } \\
\hline & $\mathbf{n}$ & $\%$ & n & $\%$ & $\mathbf{n}$ & $\%$ & n & $\%$ \\
\hline \multicolumn{9}{|c|}{ Type of Fruit } \\
\hline Known & 45 & 75 & 60 & 100 & 50 & 83.3 & 51.8 & 85 \\
\hline Unknown & 15 & 25 & 0 & 0 & 10 & 16.7 & 9 & 15 \\
\hline Total & 60 & 100 & 60 & 100 & 60 & 100 & 60 & 100 \\
\hline$T$-test & \multicolumn{4}{|c|}{$p=$ Value 0.000} & \multicolumn{4}{|c|}{$p=$ Value 0.005} \\
\hline \multicolumn{9}{|c|}{ Fruit Benefit } \\
\hline Known & 1 & 1.7 & 6 & 10 & 20 & 33.3 & 32 & 53.3 \\
\hline Unknown & 59 & 98.3 & 54 & 90 & 40 & 66.7 & 28 & 46.7 \\
\hline Total & 60 & 100 & 60 & 100 & 60 & 100 & 60 & 100 \\
\hline$T$-test & \multicolumn{4}{|c|}{$p=$ Value 0.000} & \multicolumn{4}{|c|}{$p=$ Value 0.005} \\
\hline
\end{tabular}

Table 1 shows that the majority of respondents, both treatment and control groups, know about various types of fruit. The results of statistical tests showed that there were significant differences in knowledge about the kind of fruit before and after treatment (treatment group $=p$ value 0.000 and control group $=p$-value 0.005$)$.
Table 1 also shows that most respondents did not know about the benefits of fruit. However, storytelling and health education traditionally show differences in knowledge about fruit benefits before and after treatment (treatment group $=p$-value 0.000 and control group $=p$ value 0.005$)$.

Table 2 overview of knowledge about types and benefits of vegetables before and after treatment

\begin{tabular}{|c|c|c|c|c|c|c|c|c|}
\hline \multirow{3}{*}{$\begin{array}{l}\text { Education } \\
\text { Level }\end{array}$} & \multicolumn{4}{|c|}{ Treatment } & \multicolumn{4}{|c|}{ Control } \\
\hline & \multicolumn{2}{|c|}{ Pre } & \multicolumn{2}{|c|}{ Post } & \multicolumn{2}{|c|}{ Pre } & \multicolumn{2}{|c|}{ Post } \\
\hline & $\mathbf{n}$ & $\%$ & $\mathbf{n}$ & $\%$ & $\mathbf{N}$ & $\%$ & $\mathbf{n}$ & $\%$ \\
\hline \multicolumn{9}{|c|}{ Type of } \\
\hline \multicolumn{9}{|c|}{ Vegetables } \\
\hline Known & 30 & $50 \%$ & 60 & $100 \%$ & 38 & $63 \%$ & 51 & 85 \\
\hline Unknown & 30 & $50 \%$ & 0 & & 22 & $37 \%$ & 9 & 15 \\
\hline Total & 60 & 100 & 60 & 100 & 60 & 100 & 60 & 100 \\
\hline T-test & \multicolumn{4}{|c|}{$p=$ Value 0.000} & \multicolumn{4}{|c|}{$p=$ Value 0.024} \\
\hline \multicolumn{9}{|c|}{ Vegetable Benefit } \\
\hline Known & 1 & 6.7 & 4 & 1.7 & 23 & 38.3 & 17 & 28.3 \\
\hline Unknown & 59 & 93.3 & 56 & 98.3 & 37 & 61.7 & 43 & 71.7 \\
\hline Total & 60 & 100 & 60 & 100 & 60 & 100 & 60 & 100 \\
\hline$T$-test & \multicolumn{4}{|c|}{$p=$ Value 0.000} & \multicolumn{4}{|c|}{$p=$ Value 0.106} \\
\hline
\end{tabular}

Table 2 shows that before treatment the respondents who knew about the type of vegetables in the treatment group were 29 (48.3\%), while in the control group as many as 38 (63.3\%). After being given treatment, the treatment group experienced a high increase in the number of respondents who knew the type of vegetable compared to the control group. The results of statistical tests showed that both the treatment and control groups had the same difference before and after treatment ((treatment group $=p$-value 0.000 and control group $=p$ value 0.024 ).

Table 2 also showed that most of the treatment groups did not know the benefits of vegetables,
However, after treatment, the respondent's knowledge of the benefits of vegetables increased, this was supported by the results of statistical tests showing a $\mathrm{p}$-value of 0.000 . This indicates that there were differences in knowledge of vegetable benefits before and after treatment. In the control group, there were $23(38.3 \%)$ respondents who knew about the benefits of vegetables, after treatment respondents who knew vegetable benefits only increased to $37(61.7 \%)$. The results of statistical tests showed p-value 0.106. This indicates that there is no difference before and after the provision of traditional health education to knowledge about the benefits of vegetables 
Table 3 Overview of Practical Ability Fruit Consumption before and after Treatment

\begin{tabular}{|c|c|c|c|c|c|c|c|c|}
\hline \multirow{3}{*}{$\begin{array}{l}\text { Fruit } \\
\text { Practical } \\
\text { Consumption }\end{array}$} & \multicolumn{4}{|c|}{ Treatment } & \multicolumn{4}{|c|}{ Control } \\
\hline & \multicolumn{2}{|c|}{ Pre } & \multicolumn{2}{|c|}{ Post } & \multicolumn{2}{|c|}{ Pre } & \multicolumn{2}{|c|}{ Post } \\
\hline & $\mathbf{n}$ & $\%$ & $\mathbf{n}$ & $\%$ & n & $\%$ & $\mathbf{n}$ & $\%$ \\
\hline Consume & 21 & $35 \%$ & 59 & $98.3 \%$ & 21 & $35 \%$ & 23 & 38.5 \\
\hline Not Consume & 39 & $65 \%$ & 1 & 1.7 & 39 & $65 \%$ & 37 & 61.5 \\
\hline Total & 60 & 100 & 60 & 100 & 60 & 100 & 60 & 100 \\
\hline$T$-test & \multicolumn{4}{|c|}{$p=$ Value 0.000} & \multicolumn{4}{|c|}{$p=$ Value 0.000} \\
\hline
\end{tabular}

Table 3 showed that in the treatment group there was a significant increase regarding the number of respondents who were able to practice fruit-eating as many as $59(98.3 \%)$ respondents, while in the control group only $23(38.5 \%)$. The results of statistical tests showed that the two groups had differences in the practice of eating fruit before and after treatment ( $p$-value 0.000).

Table 4 Overview of Practical Ability Vegetable Consumption Before and After Treatment

\begin{tabular}{|c|c|c|c|c|c|c|c|c|}
\hline \multirow{3}{*}{$\begin{array}{l}\text { Vegetable } \\
\text { Practical } \\
\text { Consumption }\end{array}$} & \multicolumn{4}{|c|}{ Treatment } & \multicolumn{4}{|c|}{ Control } \\
\hline & \multicolumn{2}{|c|}{ Pre } & \multicolumn{2}{|c|}{ Post } & \multicolumn{2}{|c|}{ Pre } & \multicolumn{2}{|c|}{ Post } \\
\hline & $\mathbf{n}$ & $\%$ & $\mathbf{N}$ & $\%$ & $\mathbf{n}$ & $\%$ & $\mathbf{n}$ & $\%$ \\
\hline Consume & 22 & $36.7 \%$ & 56.4 & $93.3 \%$ & 22 & $36.7 \%$ & 23 & 38.5 \\
\hline Not Consume & 38 & $63.3 \%$ & 4 & 6.7 & 38 & $63.3 \%$ & 37 & 61.5 \\
\hline Total & 60 & 100 & 60 & 100 & 60 & 100 & 60 & 100 \\
\hline$T$-test & \multicolumn{4}{|c|}{$p=$ Value 0.000} & \multicolumn{4}{|c|}{$p=$ Value 0.000} \\
\hline
\end{tabular}

Table 4 shows that in the treatment group there were $56(93.3 \%)$ who were able to practice eating vegetables, while in the control group only 23 $(38.5 \%)$. The statistical test results showed that in the treatment group there were differences before and after storytelling using media booklets on the ability to eat vegetables ( $p$-value 0.000), whereas in the control group there were no differences before and after traditional health education on the ability to practice vegetable eating ( $p$-value 0.088 ) From some of the descriptions above, the results of this study are in line with previous research that good knowledge will increase a person's awareness of eating fruit. This is supported by the research of Kristjandottir et al. (2006) that knowledge about benefits and recommendations for fruit consumption is directly proportional to fruit consumption in children.

The results of the study also showed that the two groups had knowledge of various types of vegetables, but there were still many respondents who did not have awareness about the benefits of vegetables. Even in the control group, there was a decrease in the number of respondents who knew vegetable benefits. This condition is in line with the ability to practice eating vegetables.

In the treatment group, the existence of knowledge about the types and benefits of vegetables made respondents have the ability to practice eating vegetables. Even the data shows that after storytelling using booklet media on the types and benefits of vegetables there were 56 $(93.3 \%)$ respondents who consumed vegetables.

In contrast to the treatment group, in the control group of respondents who knew the benefits of vegetables only $17(28.3 \%)$ respondents. The results of the analysis show that at least the respondents knew about the benefits of vegetables because the information provided was unclear and unattractive. This condition has an impact on vegetable consumption practices. The results of vegetable consumption practices in the control group were only $23(38.5 \%)$ respondents.

The difference in the results of the two groups can be due to the method used. In the control group, health education is only given using traditional methods, namely by telling stories without using media. Media is one important component in providing health education, especially in preschool age. The media can transfer information faster to children. Media can also stimulate the senses in children so that the acceptance of the information supplied is quickly captured.

This is proven by the application of method storytelling using booklet media in the intervention group. The use of booklet media 
serves as a teaching aid to attract children's interest in the process of storytelling (Humaniora, 2018). Various types of fruits and vegetables can be shown through the images used in this study. Symbol manipulation is an essential characteristic of the stages of preschool children. In pre-school age the ability of children to be in the ability to use symbolic images in thinking (Syaodih, 2011). In addition, children get clear and tangible visualization of the images shown through the booklet, in this case, the storytelling can present information and messages through sound and pictures (audio and visual) so that it is easier for children to understand the contents of information.

Storytelling with media booklet is one of the learning methods that are suitable for preschoolers. When the process of storytelling takes place, the narrator conveys an absorption of knowledge to the audience. This process is the experience of a child (Ochs, 2009). Children adopt stories told by storytellers which contain good messages to enjoy eating fruit and vegetables so that children's knowledge increases which are indicated by the increase in respondents' knowledge which has an impact on the ability to practice fruit eating.

Delivery techniques and methods are essential factors that can support the success of information transfer. The purpose of delivering information must adjust to the needs. The method used must be following the characteristics of the group that will receive the information. The advantage of a storytelling method is that the story can be a vehicle for sharpening imagination, opening understanding and learning to the characters' experiences in the fairy tale. The storytelling technique is a unique, exciting way without being forced and without needing to patronize the child (Fihtri, 2017).

\section{Conclusion}

Storytelling is a method of delivering information that is appropriate for preschoolers. The results of the pre-test and post-test in the treatment group showed that there was a significant effect of the application of storytelling to the knowledge of fruit and vegetable consumption. Knowledge of fruits and vegetables in children will be very supportive of the attitudes and behavior of children to consume them. When children know about the benefits of consuming fruits and vegetables, children will be interested in trying to consume them

\section{Bibliography}

1. Bestari, G.S. And Pramono, A., 2014. Pengaruh Edukasi Gizi Menggunakan Media Buku Cerita Bergambar Terhadap Perubahan Konsumsi Buah Dan Sayur Anak Di Paud Cemara, Semarang (Doctoral Dissertation, Diponegoro University).

2. Fithri, D.L. And Setiawan, D.A., 2017. Analisa Dan Perancangan Game Edukasi Sebagai Motivasi Belajar Untuk Anak Usia Dini. Simetris: Jurnal Teknik Mesin, Elektro Dan Ilmu Komputer, 8(1), Pp.225230.

3. Fibrihirzani, H., 2012. Hubungan Antara KarakteristikIndividu, OrangTua Dan Lingkungan Dengan Konsumsi Buah Dan Sayur Pada Siswa SDN Beji 5 Dan 7 Depok Tahun 2012.[Skripsi]. Depok: Universitas Indonesia.

4. Hikmah, K., KUNTJORO, T. And ARISTIATI, K., 2016. ANALISIS FAKTOR-FAKTOR RISIKO KETERLAMBATAN PERKEMBANGAN ANAK BALITA DI KABUPATEN KUDUS (Doctoral Dissertation, Postgraduate Program)

5. Humaniora, S., 2018. ANALYSIS ON CHILDREN ENTHUSIASM TOWARD STORYTELLING ACTIVITIES IN RUMAH BACA HARAPAN BULUKUMBA (Doctoral Dissertation, STATE ISLAMIC UNIVERSITY).

6. Kania, N., 2006. Stimulasi Tumbuh Kembang Anak Untuk Mencapai Tumbuh Kembang Yang Optimal. In Seminar 
Stimulasi Tumbuh Kembang, Bandung

(Vol. 11).

7. Kristjansdottir, A.G., Thorsdottir, I., De Bourdeaudhuij, I., Due, P., Wind, M. And Klepp, K.I., 2006. Determinants Of Fruit And Vegetable Intake Among 11-YearOld Schoolchildren In A Country Of Traditionally Low Fruit And Vegetable Consumption. International Journal of Behavioral Nutrition And Physical Activity, 3(1), P.41.

8. Lubis, B.M., Tingkat Pengetahuan AnakAnak Sekolah Dasar Tentang Manfaat Konsumsi Sayur-Mayur Di Sekolah Dasar Shafiyyatul Amaliyyah Medan

9. Ochs, E. And Capps, L., 2009. Living Narrative: Creating Lives In Everyday Storytelling. Harvard University Press.

10. Persada, P.R., Kerlinger, F.N. And Nazir, M., Adriana, D.(2011). TumbuhKembang Dan Terapi Bermain Pada Anak. Jakarta: Salemba Medika. Agus Efendi.(2005). Revolusi Kecerdasan Abad 21. Bandung: Alfabeta Chaplin, JP (1981). Kamus Lengkap Psikologi (Kartini Kartono Trans). Jakarta.

11. Rohimah, E., Kustiyah, L. And Hernawati, N., 2015. Pola Konsumsi, Status Kesehatan Dan Hubungannya Dengan Status Gizi Dan Perkembangan Balita. Jurnal Gizi Dan Pangan, 10(2).

12. Suyitno, H. And Narendra, M.B., 2002. Pertumbuhan Fisik Anak. Dalam Buku Ajar Tumbuh Kembang Anak Dan Remaja. Editor MB Narendra, TS Sularyo, Soetjiningsih, H. Suyitno, IG. NG Ranuh. Edisi Pertama. Cetakan Pertama. Sagung Seto. Jakarta.

13. Syaodih, E. And Agustin, M., 2011. Bimbingan Konseling Untuk Anak Usia Dini; Edisi 1 Modul 1-9. 